\title{
Do Students of Mining and Allied Engineering Programmes have any Problems in English?*
}

\author{
P. B. Mireku-Gyimah
}

Mireku-Gyimah, P. B. (2008). "Do Students of Mining and Allied Engineering Programmes have any Prob-

lems in English?”, Ghana Mining Journal, pp. 48 - 62

\begin{abstract}
In recent times, concerns about the falling standard of English among university students in Ghana have generated many studies, which have focused mainly on analysis of errors in the English of students, using test-based extracted data such as student examination scripts or students' responses to questionnaires and interviews specially designed for the purpose. These studies have usually centred on undergraduate students but none has involved the students of University of Mines and Technology (UMaT). This paper studies the standard of English among undergraduates of UMaT, who are all students of mining and allied engineering programmes. Unlike previous studies, the data comprise 498 faulty sentences selected from comments written by the students on their lecturers' teaching performance. This source of data is not test-based because the students write the comments anonymously, at their leisure and without knowing that the errors they commit could be used to assess their competence level in English. The comments therefore reflect the English that the students normally know. The faults detected in the comments are categorised into nine error types and the frequency of occurrence calculated for each category. Samples from each category are tabulated and analysed while assigning plausible reasons for the errors and suggesting corrections. The analysis shows that the most frequently occurring errors involve wrong register (wrong tone of language and vocabulary misuse) and wrong concord (subject-verb disagreement) while the least frequently occurring ones involve wrong punctuation and capitalisation as well as wrong adjective, adverb and pronoun usage. The findings indicate that the students have difficulties in expressing themselves in formal, written English owing to limited lexicon and inadequate knowledge in English grammar, usage and style. To reverse the situation, it is suggested that the Communication Skills course be extended beyond the current first year of undergraduate study and given more emphasis.
\end{abstract}

\section{Introduction}

For many years, there has been a general concern about the falling standard of English in Ghana. Studies by Criper (1971) and Sey (1973) point to deviations which confirm this concern. Gyasi (1990) sums up the problems as follows:

English in Ghana is very ill. The cancerous tumours are countless: wrong collocation; false concord; poor spelling due to unfamiliarity with the word or to mispronunciation; inability to handle the third person singular in particular ... the tenses ... generally; wrong insertion or omission of the articles; misuse of prepositions; errors arising from mother tongue interference; paucity of vocabulary, etc.

The cancer has spread too and is to be found everywhere: in the English of teachers, journalists, other professionals, ordinary men and women, and students from the secondary school to the university (p. 24).

Many causes have been noted. For example, Gyasi (1990) cites the dearth of qualified teachers and textbooks as well as the absence of a reading habit as some of the causes. Adu-Darko et al. (2008) consider that the use of Pidgin English by students at both the pre-university and university levels is a contributing factor to the menace. In spite of interventions such as the introduction of new English textbooks and adoption of new methods to teach English in our schools, studies by Hyde (1988), Bawa (1992), Tettey (1996), Dzontoh (1996), Twum-Barimah (1996), Yankyera (1996), EduBuandoh (1997), Gyening (2008) and Nkansah et al. (2008) indicate that a poor standard of English persists among students in our senior high schools. The Chief Examiner's Reports from the West African Examinations Council (WAEC) have also continued to confirm the shortcomings of preuniversity students in English (e.g. Anon, 1998, 1999; 2003 and 2005).

The situation is no better in our universities. Indeed, over the last one and a half decades, general concerns about the falling standard of English among university students in Ghana have prompted a number of studies including those in the University of Ghana (UG) by Odamtten et al. (1994), Dako (1997) and Anyidoho (2002); in the University of Education, Winneba (UEW) by Dako et al. (1997) and Gogovi (1997); and in the University of Cape Coast (UCC) by Gbeze (1997) and Awuah-Boateng (1998). In sum, the findings of these studies show that our university students commit errors related to wrong concord, wrong

\footnotetext{
* Manuscript received April 02, 2008

Revised version accepted November 11, 2008
} 
tense, wrong use of the preposition, the conjunction and other parts of speech as well as determiners. Other errors of the students involve misspelling and misuse of words, wrong collocation, ambiguity, unidiomatic expressions, wrong punctuation and misuse of capital and small letters.

The studies on the standard of English among university students have focused on undergraduate students mostly pursuing studies in the Arts/ Languages/Humanities/Social Sciences. In the main, test-based extracted data have been used including students' examination scripts and/or questionnaires and interviews specially administered for the purpose. In such an approach, the students are aware that their competence in English is being assessed. They may therefore be tempted to use certain words and expressions which they think would impress their examiners but which, unfortunately, are wrong. Also, as suggested by Gbeze (1997), students' anxiety as a result of examination pressure can force them to make mistakes.

This paper is the first to study the standard of English among the students of University of Mines and Technology (UMaT), who are all engineering students pursuing programmes in Mining, Mineral, Geomatic, Geological, Electrical and Electronics, and Mechanical Engineering and the source of data is not test-based. The data comprise students' comments about their course lecturers' teaching performance, which forms part of their responses to a questionnaire whose objective is not to assess students' competence in English. The questionnaire is familiar to the students because they complete it at the end of each semester. Moreover, they answer the questions anonymously and at their leisure. Under these conditions, the students are unaware that their competence in English is being assessed. They are therefore relaxed, and they express themselves in the English that they normally know. The main reason for using this source of data is that, at UMaT, the students study Communication Skills I and II in English in the first and second semesters of Year One respectively. The Communication Skills courses offer remedial lessons aimed at correcting common errors. At the end of the first year, therefore, every undergraduate student taking part in the course lecturer assessment exercise would have completed both courses in Communication Skills and is expected to communicate satisfactorily in English.

\section{Aim of Study}

The aim of this paper is to assess the level of proficiency of UMaT students in English. The paper attempts to find out what errors UMaT students commit, why they commit these errors and how they can avoid them. It is intended to study the nature of difficulties which these students have in English by posing the question: Do students of mining and allied engineering programmes have any problems in English? It is assumed that UMaT students have problems in English which are similar to those of students from other Ghanaian universities. This paper will add to the body of studies on the competence of university students in English.

\section{Methodology, Data Collection and Analysis}

A specially prepared questionnaire is offered to all UMaT students to assess course lecturers' teaching performance at the end of each semester. The modus operandi is for the students to anonymously but objectively complete, at their leisure, a questionnaire for each course taken. The various questions fall under four headings which are the major areas of the assessment: Course Presentation, Mode of Delivery, Lecturer's Bearing in Class and Pedagogy. The students select answers to the questionnaire from numbered responses ranging from 5 to 1 (5 Highest: Very Good (very satisfied) and 1 Lowest: Very Poor (not satisfied at all). However, part of the questionnaire permits the students to write down any comments they may have on their courses and/or lecturers. The questionnaire is administered by the Planning and Quality Assurance Unit (PQAU) of UMaT which compiles the responses, unedited, and analyses them to rate and rank lecturers in order to help them identify their strengths and weaknesses. The compilation leads to the PQAU document titled "Assessment of Course Lecturer Performance".

The PQAU's Assessment of Course Lecturer Performance (ACLP) for the second semester of the $2005 / 2006$ academic year is used as the source of data for this study. The ACLP covers the comments of all four year groups of students (First Year to Fourth/Final Year) offering the six mining and related engineering programmes (Mining, Mineral, Geomatic, Geological, Electrical and Electronics, and Mechanical Engineering). Out of the total UMaT undergraduate student population of 1000 , about 800 constituting $80 \%$ took part in the course lecturer assessment exercise at the end of the second semester of the 2005/2006 academic year.

All the unedited students' comments from the ACLP, numbering about 2000 (specifically 1 997), were extracted and studied to identify the type of problems students have in English. Subsequently, about 500 problem sentences (specifically 498) forming nearly a quarter of all the comments were identified. Admittedly, not all the participating students committed errors but, on the whole, 
Table 1 Frequency of Occurrence of Errors

\begin{tabular}{|c|c|c|c|}
\hline SN & Category of Error & Number of Errors & Percentage Error (\%) \\
\hline 1. & $\begin{array}{c}\text { Wrong Register (Wrong Tone of Language and } \\
\text { Wrong Choice of Lexical Item/Vocabulary) }\end{array}$ & 82 & 16.47 \\
\hline 2. & Wrong Concord (Subject-Verb Disagreement) & 74 & 14.86 \\
\hline 3. & Awkward Expressions & 72 & 14.46 \\
\hline 4. & Ambiguity & 66 & 13.25 \\
\hline 5. & Wrong Tense Usage & 57 & 9.44 \\
\hline 6. & Wrong Preposition Usage & 49 & 8.23 \\
\hline 7. & $\begin{array}{c}\text { Omission of the Indefinite Article and Misuse of } \\
\text { the Apostrophe and S ('S) }\end{array}$ & 41 & 6.63 \\
\hline 8. & Wrong Adjective, Adverb and Pronoun Usage & 33 & 4.82 \\
\hline 9. & Wrong Punctuation and Capitalisation & 24 & $\mathbf{1 0 0 . 0 0}$ \\
\hline \multicolumn{2}{r}{} & $\mathbf{4 9 8}$ & \\
\hline
\end{tabular}

the problem sentences show that some students have problems in English. The problem sentences were categorised into nine error types while trying to minimize the extensive overlaps. The frequency of occurrence of each error type was calculated. Sample errors were then taken from each category and tabulated in descending order, according to frequency of occurrence (see Table 1). The analysis indicates that the most frequently occurring errors of the students involve wrong register (wrong tone of language and wrong choice of lexical item/vocabulary); wrong concord (subject-verb disagreement); and awkward expressions while the least frequently occurring errors relate to wrong punctuation and capitalisation; wrong adjective, adverb and pronoun usage; and omission of the indefinite article and misuse of the apostrophe and $s$ ('s).

\section{Findings and Discussion}

\subsection{Wrong Register}

Wrong register as a category records a frequency of occurrence of 82 or $16.47 \%$ and ranks first. Table $2 \mathrm{a}$ and Table $2 \mathrm{~b}$ show examples of the students' errors involving the use of wrong register. We use the term "register" here to mean three things: (i) language usage which is the tone of language that reflects our attitude to the audience; (ii) the choice of specific vocabulary associated with a subject under discussion such as mining, engineering and the university; and (iii) the choice of lexical item or other use of vocabulary, generally. Quirk and Greenbaum (2000) view the first two respectively as: (i) varieties according to attitude and (ii) varieties according to subject matter.

In Table 2a, we note in Examples 2.1 to 2.4 that the tone of language used by the students does not show any distance between them and their lecturers. To speak and write in the appropriate register is of immense importance in any society. Ghanaians are taught how to speak to whom at home, but when it comes to writing, they flounder. The situation we are looking at is: students are assessing their lecturers. But the language we find in the examples echoes the language used in the students' pre-university school reports: "He should buck up!" and "Should keep it up!" This language is inappropriate in this discourse situation. The students are expected to comment on the performance of their lecturers, and not to give advice. The data reveal that they are neither aware of formal language use in a given situational context nor sensitive to the different roles of lecturers and students. They ought to show the distance between them and their lecturers and thereby express deference. Therefore, the students should avoid the use of "should" in their comments and write simple statements such as: The lecturer performs excellently at lectures. or The lecturer performs poorly at lectures.

Table $2 \mathrm{~b}$ presents the students' wrong choice of lexical item or vocabulary. We note that in Examples 2.5 to 2.7, the students are unable to use the specific vocabulary to talk about university administration as the subject matter. The use of "board" (see Example 2.5) in place of the correct

Table 2a Wrong Register (Wrong Tone of Language)

\begin{tabular}{|c|c|c|c|}
\hline Example & Students' Comment & What is Wrong & Suggested Correction(s) \\
\hline 2.1 & He should buck up! & 1. Inappropriate language use: & $\begin{array}{l}\text { In writing their comments, the } \\
\text { students must write simple statements }\end{array}$ \\
\hline 2.2 & Should keep it up! & $\begin{array}{l}\text { "Should" in Examples 2.1-2.4 suggests } \\
\text { informality (lack of distance) and lack }\end{array}$ & without "should". \\
\hline 2.3 & Should learn to teach according to handout. & $\begin{array}{l}\text { 2. Students are required to comment, } \\
\text { not to give advice. }\end{array}$ & $\begin{array}{l}\text { corforms excellently with regard to } \\
\text { course delivery. } \\
\text { or }\end{array}$ \\
\hline 2.4 & $\begin{array}{l}\text { Should present materials in a much more } \\
\text { presentable manner. }\end{array}$ & & $\begin{array}{l}\text { The lecturer does not teach well./The } \\
\text { lecturer does not present his materials } \\
\text { well. }\end{array}$ \\
\hline
\end{tabular}


register, council, could be attributed to the fact that the students know that the highest governing body of second cycle schools is a Board (Board of Governors) but they do not know that that of a university is a Council (University Council). In this case, the students obviously use the item they know: the school board. Indeed "board", "classes" and "term" are words commonly associated with the second cycle schools from where the students last graduated. At the university, we expect the use of "council", "lectures" and "semester".
The use of "advises" as the plural of advice (noun) and "thesis" as that of theses in Examples 2.8 and 2.9 , respectively, also indicate that the students do not have sufficient knowledge about the plural forms of some irregular nouns. In the case of thesis (singular, pronounced $/ \theta \mathrm{i}: \mathrm{sis} /$ ), we expect the students to have known the plural form to be theses (pronounced / $\theta \mathrm{i}: \mathrm{si}: \mathrm{z} /$ ) since both forms are common words in the university. Probably, the students have not noticed the difference in spelling because they wrongly pronounce both words the

\section{Table 2 (b) Wrong Register (Wrong Choice of Lexical Item/Vocabulary)}

\begin{tabular}{|c|c|c|c|}
\hline Example & Students' Comment & What is Wrong & Suggested Correction(s) \\
\hline 2.5 & $\begin{array}{l}\text {...needs to be acknowledged and given proper } \\
\text { incentives by the board of this university } \\
\text { because... }\end{array}$ & board & council \\
\hline 2.6 & ...comes to classes late... & classes & lectures \\
\hline 2.7 & $\ldots$ worked very hard this term. & term & semester \\
\hline 2.8 & $\begin{array}{l}\text {... was not only a lecturer to us but also a } \\
\text { father with all those wonderful advises. }\end{array}$ & $\begin{array}{l}\text { the plural form as } \\
\text { advises }\end{array}$ & $\begin{array}{c}\text { pieces of advice (note also the spelling } \\
\text { with "c") }\end{array}$ \\
\hline 2.9 & $\begin{array}{l}\text { His mid-sems are like end of sems and his end } \\
\text { of sem exams are like thesis. }\end{array}$ & $\begin{array}{l}\text { thesis, singular; plural form of thesis } \\
\text { expected }\end{array}$ & theses; $\ldots$ are like theses. \\
\hline 2.10 & He has got good agendas for the university. & agendas & plans \\
\hline 2.11 & $\begin{array}{l}\text { If the department could have more of such } \\
\text { people, UMaT... }\end{array}$ & people & lecturers \\
\hline 2.12 & $\begin{array}{l}\text {...the Assistant Lecturer is good, but the } \\
\text { things that he teaches... }\end{array}$ & things & topics \\
\hline 2.13 & Lab should be updated. & updated & upgraded, renovated \\
\hline 2.14 & $\begin{array}{l}\text { Hardworking ....willing to impact all the } \\
\text { knowledge ... }\end{array}$ & impact & impart \\
\hline 2.15 & ...is an expect in certain parts of the course. & expect & expert \\
\hline 2.16 & The way he teaches is quiet boring. & quiet & quite \\
\hline 2.17 & Students "chew and poor". & poor & pour \\
\hline 2.18 & He should give the students space to breath. & breath (noun); verb needed & breathe \\
\hline 2.19 & Least I forget he is a real gentleman. & least & lest \\
\hline 2.20 & $\begin{array}{l}\text { Lectures turn to become boring./Students } \\
\text { turns up sleeping in his lectures. }\end{array}$ & turn/turns up & tend to become... /tend to sleep... \\
\hline 2.21 & He has a very good report with his students. & report & rapport, relationship \\
\hline 2.22 & ... to be awarded for good work done. & awarded & rewarded (or awarded a prize..) \\
\hline 2.23 & $\begin{array}{l}\ldots \text { to be recommended for good work done } \\
\text { this semester. }\end{array}$ & recommended & commended, complimented \\
\hline 2.24 & $\begin{array}{l}\text { He should learn to deliver his knowledge } \\
\text { well. }\end{array}$ & deliver & impart \\
\hline 2.25 & $\begin{array}{l}\text { He is too patient and students take } \\
\text { opportunity of that and misbehave. }\end{array}$ & (take) opportunity (of)....and... & (take) advantage (of)...to \\
\hline 2.26 & He has a poor mode of delivering. & $\begin{array}{l}\text {... delivering (progressive; unidiomatic) } \\
\text { noun needed }\end{array}$ & ... delivery \\
\hline 2.27 & $\begin{array}{l}\text { He jeopardizes us by bringing difficult } \\
\text { questions in our exams. }\end{array}$ & jeopardizes & disturbs/troubles/worries \\
\hline 2.28 & $\begin{array}{c}\text { More of such innovated lecturers should be } \\
\text { employed. }\end{array}$ & innovated (simple adjective needed) & innovative \\
\hline 2.29 & ... very discipline lecturer. & $\begin{array}{l}\text { discipline (verbal adjective needed: + } \\
-(e) d / \text { past (participle) }\end{array}$ & disciplined \\
\hline
\end{tabular}


same way.

Further, in Example 2.10, "He has got good agendas for the university", the students use "agendas" instead of the more appropriate word, "plans". In Examples 2.11 and 2.12, they use the vague words: "people" and "things", instead of the more concise words, lecturers and topics. The use of "updated", "impact", "expect”, "quiet", "breath", "poor", "least”, "turn" (up) and "report" instead of upgraded, impart, expert, quite, breathe, pour, lest, tend and rapport in Examples 2.13 to 2.21 is the result of either the students' confusion of words that sound or look alike or their inability to pronounce and spell such words correctly. Incidentally, these are mistakes involving pairs of words of high frequency. We note that the errors involving these pairs of words also lead to malapropism, which further points to the students' incomplete knowledge about the word they intend to use.

We observe that, in the data, the only major spelling errors are those created by the vocabulary errors here, which may be identified as wrong spelling resulting in the creation of new words that are then used wrongly. Notably, "turn" for tend (see Example 2.20 where it is not only "turn" but also the phrasal verb, "turn up", which is also confused with tend) and the confounding of reward and "award" and commend and "recommend" (see Examples 2.22 and 2.23) are very common errors in Ghanaian writing.

We also note problems related to collocation. In Example 2.24, the students use "deliver" probably influenced by the collocation: deliver a lecturel impart knowledge and we get a mixed collocation. In Example 2.25 also, they mix up the verb take with the noun opportunity to give a wrong expression: "take opportunity of" instead of the idiom take advantage of. Moreover, in Example 2.26, we find that they exchange the noun delivery with the progressive form of the verb deliver, delivering, to produce the non-standard expression: "a poor mode of delivering". The idiom is a poor mode of delivery not "a poor mode of delivering". In English, idioms are characteristically fixed; they are not transparent in meaning and they are grammatically immobile.

In Example 2.27, the use of "jeopardize" in "He jeopardizes us..." appears to be the result of the student's desire to sound flamboyant. Sey (1973) refers to such a motivation as preciosity and defines the term as "the preference for learned words and phrases in contexts where more familiar expressions would be more appropriate" (p. 127). As suggested in the table, the students can use a simple word such as disturbs/troubles/worries instead of "jeopardizes".
In Example 2.28, while the use of "innovated" in “... innovated lecturers..." may be another attempt at preciosity, we note that the students seem to be ignorant of the adjective innovative and try to approximate a form of the past participle (-ed participle) "innovated", which is erroneous. The use of the past participle is probably informed by the students' awareness of the adjectival use of the past participle as in concerned citizen and disciplined students. The two adjectival forms - the simple adjective and the past participle - are not in free variation and, as Sey (1973) suggests, if this is not noticed early enough in school, it leads to nonidiomatic use. Unfortunately, we observe that when it becomes necessary to use the verbal adjective, the students are unable to handle the adjectival use of the past participle as we detect in Example 2.29: “... very discipline lecturer." instead of ... very disciplined lecturer. This shows that the students' understanding of the verbal adjective is inadequate.

\subsection{Wrong Concord (Subject-Verb Disagree- ment)}

Table 3 presents errors of concord. The frequency of occurrence of wrong concord is 74 or $14.86 \%$ and, as a category, it ranks second. Wrong concord is thus revealed as a major grammatical problem. Errors involving mismatching of singular subjects and plural verbs or plural subjects and

singular verbs are the most common in the students' comments. The concord rule is that a singular subject matches a singular verb and a plural subject matches a plural verb. Examples 3.1 to 3.4 show the third person singular verb without the final $s$ as in "fidget", "seem", "exist" and "suggest" instead of fidgets, seems, exists and suggests, causing a disagreement between the subjects and the verbs. Example 3.5 also presents a similar problem in the second part of the compound sentence because He... does n't... is wrongly written as “(He) don't ...”. While one part of the sentence obeys the concord rule (He is ...), the other does not ("He don't..."). This is an example of what Yankson (1994) describes as "asystematic errors" (p. 6) and they arise as a result of subject-verb concord inconsistencies in the same sentence. Furthermore, we find that plural subjects do not agree with their verbs. Examples 3.6 and 3.7 show this problem. We expect ... $d u$ ties keep and not "... duties keeps..." and ... comments discourage... and not "comments discourages". Example 3.8 is similar despite the introduction of the pronoun which, which might have confused the students: we expect ... courses which need ... and not "courses which needs". As in Example 3.5, we note that the rule is obeyed and disobeyed in the same sentence with (There are...) and ("... courses which needs"). Thus the rules governing subject and verb agreement are flouted 
Table 3 Wrong Concord (Subject and Verb Disagreement) etc.

\begin{tabular}{|c|c|c|c|}
\hline Example & Students' Comment & Wrong Verb Form, etc. & Suggested Word(s)/Correction \\
\hline & & $\begin{array}{l}\text { (The rule is singular subject }+ \text { singular } \\
\text { verb; plural subject }+ \text { plural verb) } \\
\text { Examples } 3.1-3.4: 3^{\text {rd }} \text { person singular } \\
\quad \text { verb forms needed: plus } s \text { : }\end{array}$ & \\
\hline 3.1 & The lecturer fidget when in class. & fidget & The lecturer...fidgets \\
\hline 3.2 & $\begin{array}{l}\text { He/She seem to know the answer to every } \\
\text { question. }\end{array}$ & seem & He/She seems... \\
\hline 3.3 & The best lecturer-student relationship exist. & exist & The ... relationship exists... \\
\hline 3.4 & It strongly suggest... & suggest & It... suggests ... \\
\hline 3.5 & $\begin{array}{l}\text { He is good but don't know how to teach } \\
\text { for students to understand him. }\end{array}$ & $\begin{array}{l}\text { Example 3.5: } \\
\text { don't: }\left(3^{\text {rd }} \text { person singular verb form }\right. \\
\text { needed: i.e. }+ \text { es in the negative })\end{array}$ & $\begin{array}{c}\text { He ... doesn't /(He is good but (he) } \\
\text { doesn't...) }\end{array}$ \\
\hline 3.6 & Other duties keeps him ... & $\begin{array}{l}\text { Examples } 3.6 \text { and } 3.7: \text { keeps, } \\
\text { discourages: }\end{array}$ & Other duties keep him... \\
\hline 3.7 & His comments discourages us. & $\begin{array}{l}\left(3^{\text {rd }} \text { person plural verb forms needed i.e. }\right. \\
\text { without } s: \text { keep, discourage) }\end{array}$ & His comments discourage us. \\
\hline 3.8 & $\begin{array}{c}\text { There are other courses which needs equal } \\
\text { attention. }\end{array}$ & $\begin{array}{l}\text { Courses... needs ( } 3^{\text {rd }} \text { person plural verb } \\
\text { form needed i.e. without } s: \text { need) }\end{array}$ & There are other courses which need ... \\
\hline 3.9 & His punctuality and reliability is ... & $\begin{array}{l}\text { Plural subjects; plural marching verb } \\
\text { needed; is, singular verb; are, the plural } \\
\text { verb is required }\end{array}$ & His punctuality and reliability are .... \\
\hline 3.10 & I suggests that the examinable content... & $\begin{array}{l}\text { suggests }, 3^{\text {rd }} \text { person singular verb; }\left(1^{\text {st }}\right. \\
\text { person singular verb form required i.e. } \\
\text { without the final s: suggest })\end{array}$ & I suggest... \\
\hline 3.11 & $\begin{array}{l}\text { The course is lengthy but still manages to } \\
\text { complete ... }\end{array}$ & $\begin{array}{c}\text {... but still manages... (missing subject: } \\
\text { a noun or a } 3^{\text {rd }} \text { person singular pronoun } \\
\text { (masculine or feminine) needed as } \\
\text { subject of the verb phrase "manages to } \\
\text { complete") }\end{array}$ & $\begin{array}{l}\text {...but the lecturer } / \text { he } / \text { she manages to } \\
\text { complete ... }\end{array}$ \\
\hline 3.12 & $\begin{array}{c}\text { The course is a very interesting one and } \\
\text { would want to continue. }\end{array}$ & $\begin{array}{l}\text {...and would want to continue. } \\
\text { (marching subject needed; appropriate } \\
\text { object is also needed) }\end{array}$ & $\ldots$ and I would want it to continue. \\
\hline 3.13 & $\begin{array}{l}\text { Shows thorough knowledge about subject } \\
\text { and always available for consultation. }\end{array}$ & $\begin{array}{l}\text {... and always available for } \\
\text { consultation. (matching verb is needed: } \\
3^{\text {rd }} \text { person singular) }\end{array}$ & $\begin{array}{l}\text { The lecturer shows thorough } \\
\text { knowledge... and (he) is always } \\
\text { available for consultation. }\end{array}$ \\
\hline 3.14 & $\begin{array}{l}\text { I think she's done well and very easy to } \\
\text { approach. }\end{array}$ & $\begin{array}{c}\text {... she's done well and very easy to } \\
\text { approach. (marching verb is needed; } \\
\text { new subject she is optional) }\end{array}$ & $\begin{array}{c}\text {... she has done well and (she) is very } \\
\text { easy to approach. }\end{array}$ \\
\hline 3.15 & $\begin{array}{c}\text { He is one of the good lecturers and a good } \\
\text { work done. }\end{array}$ & $\begin{array}{l}\ldots \text { and } * \text { a good work done. (marching } \\
\text { verb has done needed; new subject he } \\
\text { is optional) (*Notice the vital changes). }\end{array}$ & $\ldots$ and (he) has done a good work. \\
\hline 3.16 & $\begin{array}{l}\text { He missed a lot of lectures but still ... } \\
\text { makes up ... the lost time, incredible man. }\end{array}$ & $\begin{array}{l}\text { missed...makes up ... (mixture of } \\
\text { simple past and simple present; no } \\
\text { sequence of tense); missed ... made (the } \\
\text { perfective aspect), the simple past } \\
\text { needed: verb-verb concord error }\end{array}$ & $\begin{array}{l}\text {...missed a lot of lectures but (he) } \\
\text { made up the lost time... }\end{array}$ \\
\hline 3.17 & $\begin{array}{l}\text { He has to make up for lectures than always } \\
\text { trying to reschedule it. }\end{array}$ & $\begin{array}{l}\text {... the lost lectures... it (it- singular } \\
\text { pronoun - cannot replace the supposed } \\
\text { antecedent lectures - plural noun);them } \\
\text { - plural pronoun - needed: noun- } \\
\text { pronoun concord error }\end{array}$ & $\begin{array}{l}\text {...the lost lectures instead of always } \\
\text { trying to reschedule them. (He has to } \\
\text { make up for the lost lectures instead of } \\
\text { always trying to reschedule them.) }\end{array}$ \\
\hline
\end{tabular}

by the students.

We also observe that errors of concord occur in many student writings, especially in exercises, on notice boards, in letters of invitation and in programmes of students' activities. Most of these errors are corrected during Communication Skills lectures and discussions. Our experience from the 
lecture room shows two things. First, when the students are given the chance to correct themselves, some of them are usually able to do so, especially if doing so attracts a mark. Thus, theirs may be mistakes or only slips resulting from carelessness, which is known to play a role in this problem. Second, in their attempt to achieve subject and verb agreement, some students (these are the ones who would be unable to correct their faults later and for whom these faults are actually errors) try hard to mark singular and plural verbs the same way as they are taught to add $s$ to inflect the plural form of a countable noun. They treat the verbs as the countable nouns which are the subjects of those verbs. Thus they add $s$ to the verb when the noun subject is plural (and takes $s$ ) and drop it when the noun subject is singular (and does not take $s$ ). Based on this faulty reasoning, the students produce "The lecturer fidget." (Example 3.1) and "Other duties keeps him." (Example 3.6). We may ascribe the problem to poor teaching and learning of English grammar at the lower levels of the students' education. This implies that the students need extra attention to change their false idea of subject-verb agreement and master this basic aspect of English grammar.

Apart from these problems, we also find that while some constructions wrongly lack subjects (and objects) to match the verbs (see Example 3.11), others lack verbs to match their subjects (see

Examples 3.12 and 3.13). The omission of the subject lecturer (or he/she) in "The course is lengthy but still manages to complete ...." (Example 3.11) renders the sentence meaningless since course appears to be the common subject of both independent clauses and, therefore, course is the one who does the action suggested by the verb phrase "manages to complete" in the second independent clause. Certainly, "... the course manages to complete the course" is nonsensical. Example 3.12 does not only lack a subject but also the pronoun object to replace course in the second part of the compound sentence. We expect The course is a very interesting one and I would [like] it to continue. The verb-less independent clauses: “...and always available for consultation” (Example 3.13), "... and very easy to approach" and "... and a good work done" in (Examples 3.14 and 3.15) may be corrected in two ways as shown in the table by introducing the verb is to agree with the subject $h e . .$. and (he) is and also by introducing the subject together with its matching verb: she is ... to get ... and she is....In the case of Example 3.15 , the second independent clause suggested by "... and a good work done." may be rewritten correctly as: ... and (he) has done a good work. Examples 3.11 to 3.15 show that the students cannot handle the compound sentence well. With the omission of some vital sentence elements, their sentences break down right after they have managed to write the first independent clause. The errors point more to the inability of the students to combine ideas in a grammatically and semantically correct sentence.

In Example 3.16, we detect wrong sequence of tense: "missed...but...makes up..." where we expect ...missed but made up... This leads to a verbverb concord error. In Example 3.17, we observe that the singular pronoun "it" has a wrong antecedent in that it cannot replace the plural noun "lectures". We therefore require them which is a plural pronoun (in the objective case). The inconsistency between the pronoun and its antecedent creates a noun-pronoun concord error. Verb-verb and noun-pronoun concord errors are, however, not many in the corpus.

The preponderance of subject-verb concord errors in the corpus is worrying because Ghanaians frown on poor use of English and grammatical errors are considered "unworthy of an educated person" (Sey 1973). More importantly, as a topic, concord of number (subject-verb agreement), which is considered as the most important type of concord in English, is introduced quite early in Ghanaian schools. At the university level, therefore, to commit errors involving this basic type of concord, is not only intolerable and disgraceful but also it creates a bad impression about the personality of the speaker as Yankson (1994) and Owusu-Ansah (1997) have also observed.

\subsection{Awkward Expressions}

We find very awkward expressions as shown in Table 4. This category of errors ranks third with a frequency of occurrence of 72 or $14.46 \%$. In Example 4.1, "The lecturer moves quite at a fast pace and doesn't really make us follow in an understanding manner.", we assume the students want to express something in the vein of: The lecturer covers the course content quite fast so we have difficulties in understanding the gist of the lecture. Some of the students' comments in praise of their course lecturers are slangy, that is in current, youthful parlance. Thus, in Examples 4.2 to 4.4, we find "He is seriously good.", "He is too good." and "He knows the course too much." The adverb of manner "seriously" and the adverb of degree "too" (and "too much") are given meanings which are positive but not usually associated with them in such contexts. As intensifiers, these adverbials produce a heightening effect that does not sound semantically right. We can understand that He is seriously ill. means He is very ill. but we cannot write "He is seriously intelligent." to mean He is very intelligent. unless sarcasm or irony is intended. Though students can also be sarcastic, it is unlikely that they intended to be sarcastic and so 
Table 4 Awkward Expressions

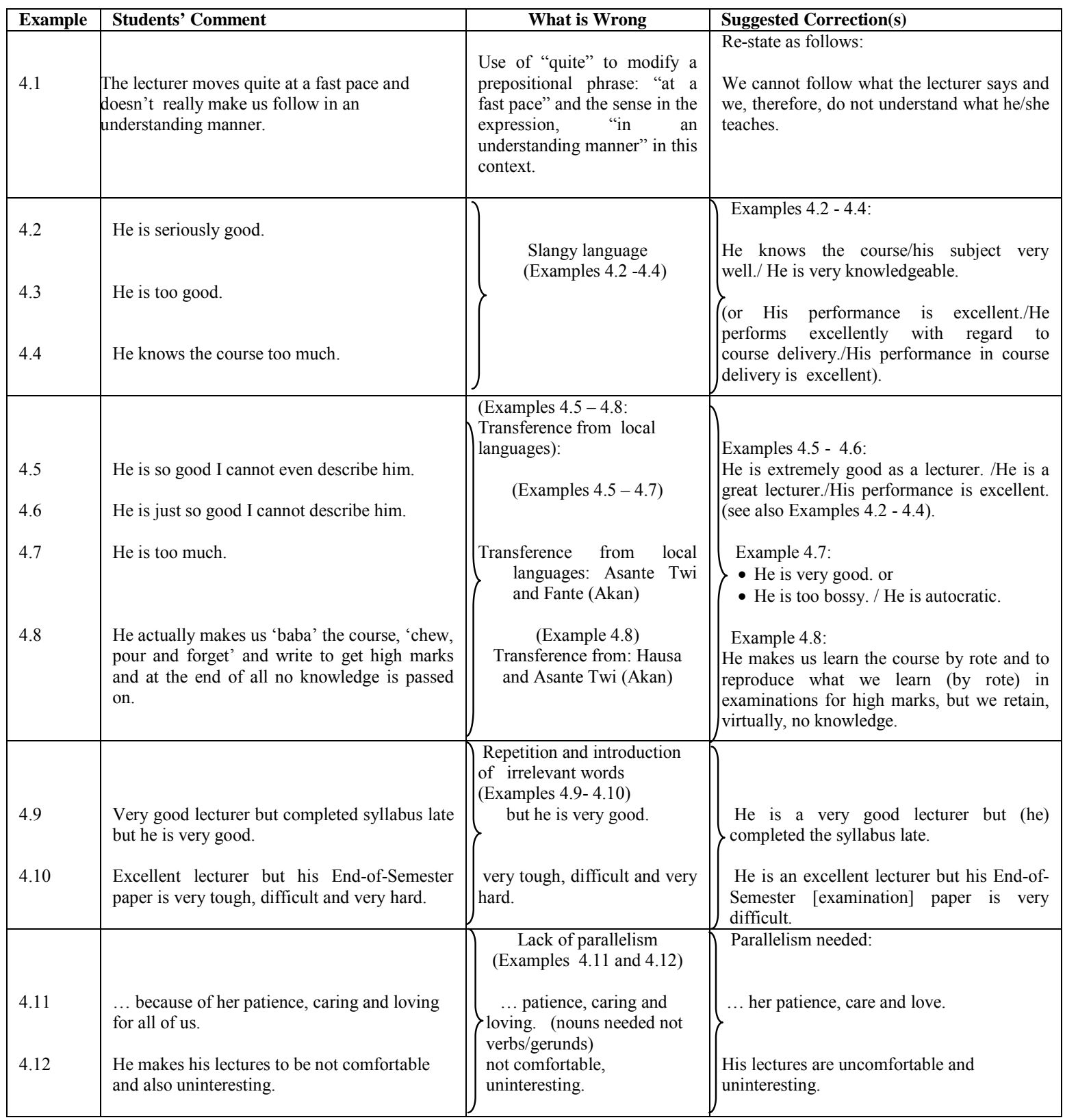

they ought to use very and very well: He is very good./He knows the course/his subject very well./ He is very knowledgeable. We, therefore, note that they lack the appropriate vocabulary to comment on their lecturers' teaching.

Further, we find that, unable to express their views in Standard English, the students convey their thoughts by falling on what appears like direct translations from local languages. Examples 4.5 and 4.6 indicate the students' praise for their lecturer. However, we note transference from a local language, Asante Twi (Akan), in that "He is so good I cannot even describe him." and "He is just so good I cannot describe him." roughly correspond to an Akan description of a person who is a considered to be a great performer: Jye adee dodo, menhunu dee menka mpo. literally meaning, $\mathrm{He} /$ She is so good (a performer) that I don't even know what to say. or He/She is so good (a performer) that I don't even know how to describe him/her. Both sentences are similar and may be rendered correctly in English as: He/She is an excellent lecturer., He/She is extremely good as a lecturer. and His/Her performance is excellent. We note that what the students mean is that the lecturer's performance is excellent: He/She performs excellently with regard to course delivery.

Example 4.7 reads "He is too much". Even though this particular construction appears to be similar to Examples 4.2 to 4.4 , it is used by the students to express both commendation and condemnation. Generally, "He/She is too much." suggests any 
behaviour of a person which the students consider to be excessive. Yet this excess can be assessed as good or bad. The phrase "Too much" then intensifies both condemnation and commendation. In either case, it is usually accompanied in speech by the appropriate gesture or facial expression which may be a frown and a fling of the hand, or a smile and a nod respectively. In written form, though the context may tell the difference, the reader cannot be very clear about the writer's intended meaning. As an expression of condemnation, "He is too much." could be traced to the Fante (Akan) expression: Jye dodow, a pejorative expression literally meaning: He/She goes overboard. So, when the students write "He is too much.", they may mean that He is bossy/autocratic/overbearing in manner. As an expression of commendation, "He/ She is too much." can be written correctly as: $\mathrm{He}$ l She is very good as a lecturer. In writing comments about their lecturer's performance, therefore, we expect students to make precise statements without leaving the reader in doubt. Thus we observe, once again, that the students in the present study fail to express themselves clearly in good English.

In Example 4.8, 'He actually makes us 'baba' the course, 'chew, pour and forget' and write to get high marks and at the end of all no knowledge is passed on.", we note Pidgin English but also transference from a local dialect, for $b a b a$ is a student slang meaning rote learning and it is of Hausa origin meaning father or master. Thus we take the words " 'baba' the course", (which is pidgin) to mean master the subject (course) and this is in turn reinforced by the word "chew", noted by Dako (2003) as a Ghanaianism meaning "study or learn by heart". Chew, the equivalent of the Akan word we, refers to the action of consuming food. This meaning is transferred to the act of mastering a subject by memorising its contents without really understanding them. Thus, in an examination, a student who has studied by mere memorisation may be able to reproduce very well ("pour") the memorised material and possibly make a high grade ("and write to get high marks") but would have acquired little or no knowledge in the particular subject or course to make it useful to him/her later. Thus such a student can only lose ("forget") the benefits thereof. We note, therefore, that transference is from Hausa and Akan dialects. We may restate the students' comment in Standard English as He makes us learn the course by rote and to reproduce what we learn (by rote) in examinations for high marks, but we retain, virtually, no knowledge. As Examples 4.2 to 4.8 have shown, students' use of non-standard English is possibly due to interference from their local languages and also the use of Pidgin English as observed by Nettey (2001) and Dako (2002).
We also observe that the students resort to repetition or use of irrelevant words in order to lay emphasis on their comments (see Examples 4.9 and 4.10). Such verbosity and redundancy render the comments clumsy, or nearly incomprehensible:

"Very good lecturer but completed syllabus late but he is very good."

"Excellent lecturer but his End-of-Semester paper is very tough, difficult and very hard."

In Example 4.10, it is likely that the students are also showing off by piling up words. Yet, economy of words, and not tautology, is the mark of good academic writing. In order to make the two comments crispy, we may state the following:

He is a very good lecturer but (he) completed the syllabus late.

He is an excellent lecturer but his End-of-Semester [examination] paper is very difficult.

Sometimes, the awkward expressions lack parallelism and are ambiguous. We note the lack of parallel structure in Example 4.11: “...patience, caring and loving...." because we require nouns in the same grammatical category as "patience". Care and love are the correct grammatical forms needed and not "caring" and "loving" which are adjectival.

\subsection{Ambiguity}

Ambiguity ranks fourth with a frequency of occurrence of 66 or $13.25 \%$. In Table 5, we find examples of ambiguous constructions because each of the statements leave the reader open to more than one interpretation and this is the result of the students' inability to state their comments succinctly. For instance, in Example 5.1, "A very discouraging lecturer" could be interpreted as either The lecturer's performance in teaching is very poor. or The lecturer does not motivate students. The ambiguity may be eliminated by stating that $\mathrm{He} / \mathrm{She}$ performs poorly as a lecturer.

Further, in Example 5.2, "Makes class interesting but not lively" could mean either The lecturer makes the class interesting and dull at the same time. or The lecturer makes the class interesting but is himself dull. and in Example 5.5, "...be a bit liberal in giving out questions" may be interpreted as either The lecturer gives students too few assignments or problems to solve. or The lecturer sets difficult questions. The ambiguity could be removed from the two respectively by writing The lecturer makes the class interesting but is himself dull (Example 5.2) and The lecturer sets difficult questions (Example 5.5). The errors of ambiguity also indicate that the students have problems of expression in English.

\subsection{Wrong Tense Usage}

This category ranks fifth with a frequency of 57 or $11.4 \%$. Table 6 presents errors in tense in the Verb 
Table 5 Ambiguity

\begin{tabular}{|c|c|c|c|}
\hline Example & Students' Comment & $\begin{array}{c}\text { What is Wrong } \\
\text { (Open to more than one meaning) }\end{array}$ & Suggested Correction(s) \\
\hline 5.1 & A very discouraging lecturer. & $\begin{array}{l}\text { His performance is poor? } \\
\text { or He does not motivate (his/her) } \\
\text { students? }\end{array}$ & $\mathrm{He} / \mathrm{She}$ performs poorly as a lecturer. \\
\hline 5.2 & Makes class interesting but not lively. & $\begin{array}{l}\text { The class is not lively? or The lecturer } \\
\text { (himself/herself) is dull (not lively)? }\end{array}$ & $\begin{array}{l}\text { He makes the class interesting but he } \\
\text { is dull. (not a lively person) } \\
\text { (himself/herself). }\end{array}$ \\
\hline 5.3 & Little improvement on his/her course. & $\begin{array}{l}\text { The (lecturer) did not improve much } \\
\text { upon his/her course (handout? } \\
\text { delivery? Remained the same?) or The } \\
\text { student assessor did not benefit much } \\
\text { from the course? }\end{array}$ & $\begin{array}{l}\text { The lecturer did not improve much } \\
\text { upon his/her course delivery. }\end{array}$ \\
\hline 5.4 & $\begin{array}{l}\text {..but he is sometimes occupied with } \\
\text { administrative work and results in the class } \\
\text { losing for that day and he does well to } \\
\text { cover up. }\end{array}$ & $\begin{array}{l}\text { Covers the lost lectures (Makes up the } \\
\text { lost time?). or hides the fact that he has } \\
\text { missed lectures? }\end{array}$ & $\begin{array}{l}\text { Covers: ... makes up the lost time: } \\
\text { He makes up the lost time. }\end{array}$ \\
\hline 5.5 & $\ldots$ be a bit liberal in giving out questions. & $\begin{array}{c}\text { To give students more questions (more } \\
\text { problems to solve?) or To show } \\
\text { questions to students? or To set easy } \\
\text { questions? }\end{array}$ & The lecturer's questions are difficult. \\
\hline
\end{tabular}

Phrase (VP). For instance, in Examples 6.1 and 6.2 respectively, the wrong forms of the verbs run and give are used with the auxiliaries were and is respectively for the passive voice as in "were ran" and "is giving" instead of were run and is given. Many Ghanaians pronounce run and ran the same way as $/ \mathrm{ran} /$ on the one hand and giving and given as $/ g I v I n /$ on the other hand. Pronunciation may thus have influenced the wrong choice of verb form. In Examples 6.3 and 6.4, the wrong forms of the verb $d o$ and bring are used instead of the simple past. In: "... some of us who have never done this course in the SSS...", the reference to the SSS (Senior Secondary School) shows that the students are talking about a past action. What they mean to say is: some of us never studied this subject in SSS. Hence we would correct the error by substituting "have done" with did. Similarly, the present tense "brings" in Example 6.4 must change to brought which is even suggested by the past reference, "on a couple of occasions": This brought confusion on a number of occasions. and not "This brings confusion on a couple of occasions."
Though tense errors are relatively few in the corpus, we observe that the students have incomplete knowledge about the simple past tense in particular and tense and aspect in general.

\subsection{Wrong Preposition Usage}

With a frequency of error of 49 or $9.84 \%$, this category of errors ranks sixth. Table 7 shows sample sentences in which prepositions are incorrectly used by the students. The prepositions to, of, from, in, with, by and about are substituted for in, during, on, to, for and of respectively. The most frequently misused preposition is in and is wrongly used for to, of and from (see Examples 7.1 to 7.4). We expect punctual to class ... and not "punctual in class" or "punctual during class" (Examples 7.1 and 7.5). In Example 7.6, the wrong use of the preposition on leads to a somewhat ridiculous expression "...start being strict on the register". The comment is intended to mean adherence to the use of the attendant register, so "strict with" appears more appropriate to use in the context than "strict on". We note the students' confusion of the correct

Table 6 Wrong Tense Usage

\begin{tabular}{|c|c|c|c|}
\hline Examples & Students' Comment & $\begin{array}{c}\text { Wrong Verb/Tense Form/Aspect / } \\
\text { Words }\end{array}$ & Suggested Tense etc. /Correction \\
\hline 6.1 & $\begin{array}{l}\text { The various courses that were ran at } \\
\text { UMaT. ... }\end{array}$ & $\begin{array}{c}\text { ran (simple past); run (past participle) } \\
\text { needed }\end{array}$ & $\ldots$ courses that were run... \\
\hline 6.2 & $\begin{array}{l}\text { Instruments must be available before the } \\
\text { work is giving out. }\end{array}$ & $\begin{array}{l}\text { giving (present participle; progressive } \\
\text { aspect); given (past participle) needed }\end{array}$ & $\ldots$ before the work is given .... \\
\hline 6.3 & $\begin{array}{l}\text { I think that there are some of us who have } \\
\text { never done this course in the SSS and ... }\end{array}$ & $\begin{array}{c}\text { have ... done (past participle); did (simple } \\
\text { past) needed }\end{array}$ & $\begin{array}{c}\text {...who never did [studied] this course } \\
\text { in the SSS .... }\end{array}$ \\
\hline 6.4 & $\begin{array}{c}\ldots \text { This brings confusion ... on a couple of } \\
\text { occasions. }\end{array}$ & brings (present); brought (simple past) & $\begin{array}{l}\text { This brought confusion on a couple of } \\
\text { occasions. }\end{array}$ \\
\hline
\end{tabular}


Table 7 Wrong Preposition Usage

\begin{tabular}{|c|c|c|c|}
\hline Example & Students' Comment & Wrong Preposition & Suggested Preposition(s)/Corrections \\
\hline 7.1 & He must be punctual in class ... & in & to \\
\hline 7.2 & The one available dates back in the days of the $1980 \mathrm{~s}$. & in & to \\
\hline 7.3 & He has in-depth knowledge in the course. & in & of \\
\hline 7.4 & $\begin{array}{l}\text { Students see the course to be "hard" because of no previous } \\
\text { knowledge in the secondary school. }\end{array}$ & in & from \\
\hline 7.5 & . and very punctual during classes. & during & to \\
\hline 7.6 & $\ldots$ start being strict on the register. & on & with (the use of the attendance register.) \\
\hline 7.7 & ... develop interest on the group work. & on & in, for \\
\hline 7.8 & ... teach in accordance to the handout given. & to & with \\
\hline 7.9 & He is an asset for the department. & for & to \\
\hline 7.10 & $\begin{array}{l}\text { I am very impressed for the introduction of a Teaching } \\
\text { Assistant. }\end{array}$ & for & by, about \\
\hline 7.11 & He makes unnecessary comments of students. & of & about \\
\hline 7.12 & A punctual lecturer of all standards. & of & by \\
\hline
\end{tabular}

forms according to and in accordance with when they wrongly substitute to for with and use the particles in and to with accordance as "in accordance to" instead of in and with as: in accordance with (see Example 7.8). The deviant use of the preposition leads to unidiomatic usage; we expect an asset to the department, and not "... an asset for ..."; impressed by and not "impressed for" (see Examples 7.9 to 7.12). Obviously, the students are unable to use prepositions correctly.

\subsection{Omission of the Indefinite Article and Mis- use of the Apostrophe and $S$}

This category of error has a frequency of occurrence of 41 or $8.23 \%$ and it ranks seventh. Examples 8.1 to 8.3 in Table 8 illustrate the omission of the indefinite article $a$. "There should be clear distinction..." should read There should be a clear distinction... (see also Examples 8.2 and 8.3). Examples 8.4 to 8.6 reveal the confusion of the students over use of $a$ (singular) or $-s$ (plural). In their confusion, they are unable to mark pronouncement and fieldtrip as singular or plural. In the case of aspect (Example 8.6) where all suggests the plural, the students are unable to write aspects: all aspects... and we get "all aspect...", which is wrong. In Examples 8.7 to 8.9, when the students try to mark plurality of the noun and also show possession, we find them deviating and misusing the apostrophe and $\mathrm{s}$ ('s). We note that they wrongly add's to mark the plural of lecturer as "lecturer's" instead of lecturers (Example 8.7). Yet when the apostrophe and $s$ are needed to indicate possession, the students fail to utilize them correctly and write "semesters work" instead of semester's work (Example 8.8) and "student's comments" instead of students' comments (Example 8.9). The errors in this category indicate that the students have imperfect knowledge about count nouns and the use of determiners.

\subsection{Wrong Adjective, Adverb and Pronoun Us- age}

This is the last but one category of errors and the frequency of occurrence is 33 or $6.63 \%$. Table 9 summarises errors involving wrong usage of the adjective, the adverb and the pronoun. We find that the comparative and superlative markers, more and most, wrongly collocate with clearer as in "more clearer" and liveliest as in "most liveliest" in Examples 9.1 and 9.2. We also find that better wrongly collocates with more as in "more better" (Example 9.3).

In addition, Examples 9.4 and 9.5 show the wrong use of the personal pronoun form: the first person plural subject "we" is used instead of the object us. Further, the third person singular form of the possessive pronoun, its, is also frequently confused with the contractions of it and is as in "it's" (Example 9.6). That the students introduce redundant items in the comparison of the adjective and the adverb and are unable to use the objective case show that they have little or no knowledge about pronoun, adjective and adverb usage.

\subsection{Wrong Punctuation and Capitalisation}

Wrong punctuation and capitalisation is the category with the least occurring frequency (24 or $4.8 \%$ ). Though deviant uses noted are very few, there is the need to correct them. Table 10 identi- 
Table 8 Omission of the Indefinite Article and Misuse of the Apostrophe and S ('S)

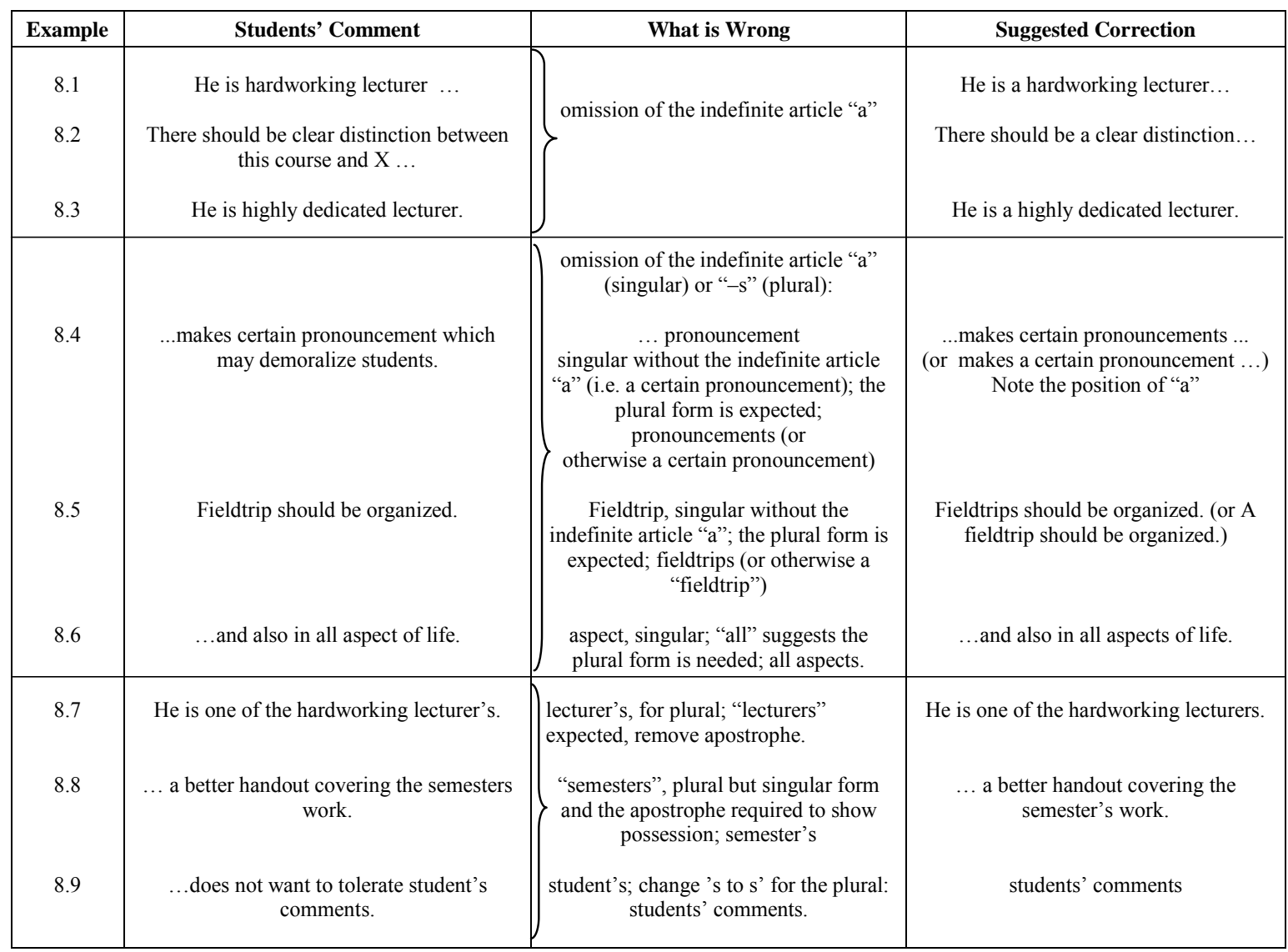

fies some of the students' errors of punctuation. In Example 10.1 the students' comment is confusing because the sentence is not punctuated: "He always carries his students along when teaching very lively in class". The run-on sentence may be corrected by introducing a semi-colon: ... when teaching; (he/she) is very lively in class. or by bringing a full stop and breaking the sentence into two: ... when teaching. He/She is very lively in class. In Example 10.2, the commas are weak so we expect the semicolon, which is a stronger pause but not yet a period. In Example 10.3, two commas are required but in Example 10.4, we do not expect the comma before because. Apart from these deviations, we also note wrong capitalisation in "Engineers" (Example 10.5) and "Excellent" and "Keep" (Example 10.6).

\section{Conclusions}

From the study, it is concluded that UMaT students have inadequate grasp of the English language. The frequency of occurrence of their errors, in descending order, are: wrong register (wrong tone of language and wrong choice of lexical item or vocabulary) (86 or $16.47 \%$ ); wrong concord (74 or $14.86 \%$ ); awkward expressions (72 or $14.46 \%$ ), ambiguity (66 or $13.25 \%$ ); wrong tense usage (57 or $11.54 \%$ ); wrong preposition usage (49 or 9.84\%); omission of the indefinite article and misuse of the apostrophe and $s$ ('s) (41 or $8.23 \%$ ); wrong adjective, adverb and pronoun usage (33 or $6.63 \%)$ and wrong punctuation and capitalisation (24 or $4.82 \%)$.

The study has revealed that UMaT students have problems in English language which make them write faulty and unidiomatic sentences. They commit very common errors in English grammar, usage, style and punctuation. Their problems in grammar include inability to mark the plural of nouns, to ensure concord, to use the past tense correctly, to use the past participle verb form as adjective, to compare adjectives and adverbs correctly and to choose the correct prepositions to express themselves clearly. Concerning usage, they are less able to communicate meaningfully. Regarding style, they are less able to write idiomatic English and they exhibit poor control in choosing the right lexical items to express their ideas concisely and effectively. Thus they are ambiguous or verbose in the presentation of their thoughts; they cannot ensure parallel structure and they fail to relate appropriately to audience. Concerning punctuation, they either refuse to punctuate what they write or they confound the punctua- 
Table 9 Wrong Adjective, Adverb and Pronoun Usage

\begin{tabular}{|c|c|c|c|}
\hline Example & Students' Comment & What is Wrong & Suggested Correction \\
\hline 9.1 & Must use more clearer formulae. & $\begin{array}{l}\text { Comparative form of adjective "clear" } \\
\text { is "clearer" ; "more" is redundant }\end{array}$ & He/She must use clearer formulae. \\
\hline 9.2 & His class is the most liveliest. & $\begin{array}{l}\text { superlative of the adjective lively is } \\
\text { liveliest; "most" is redundant }\end{array}$ & His class is the liveliest. \\
\hline 9.3 & $\begin{array}{l}\text { He can do more better than } \\
\text { now. }\end{array}$ & $\begin{array}{l}\text { "more" is redundant; the comparative } \\
\text { form of the adverb "well" is "better". }\end{array}$ & He can do better than he is doing now. \\
\hline 9.4 & $\begin{array}{l}\text { Has a good relationship with we the } \\
\text { students. }\end{array}$ & $\begin{array}{l}\text { we, should change to the objective case, } \\
\text { "us" (object of the preposition "with") }\end{array}$ & $\begin{array}{c}\text { He/She has a good relationship with } \\
\text { us the students. }\end{array}$ \\
\hline 9.5 & $\begin{array}{l}\text { If the lecturer should come down to we the } \\
\text { unfortunate ones...so that we keep pace } \\
\text { with the fortunate ones... }\end{array}$ & $\begin{array}{l}\text { the first "we" should change to the } \\
\text { objective case, "us" (object of the } \\
\text { preposition "to"). (*Note the vital } \\
\text { changes) }\end{array}$ & $\begin{array}{l}\text { If the lecturer should come down to } \\
\text { the level of us the unfortunate ones } \\
\ldots \text { so that we keep pace with the } \\
\text { fortunate ones... } \\
\text { (*Note the vital changes) }\end{array}$ \\
\hline 9.6 & ...its just that he is taking a lot of courses. & $\begin{array}{l}\text { its; (possessive); change for "it's" } \\
\text { (contracted form with 's) OR the full } \\
\text { form "it is" expected. }\end{array}$ & $\begin{array}{c}\begin{array}{c}\text {...it's / it is just that he is taking a lot } \\
\text { of courses. }\end{array}\end{array}$ \\
\hline
\end{tabular}

Table 10 Wrong Punctuation and Capitalisation

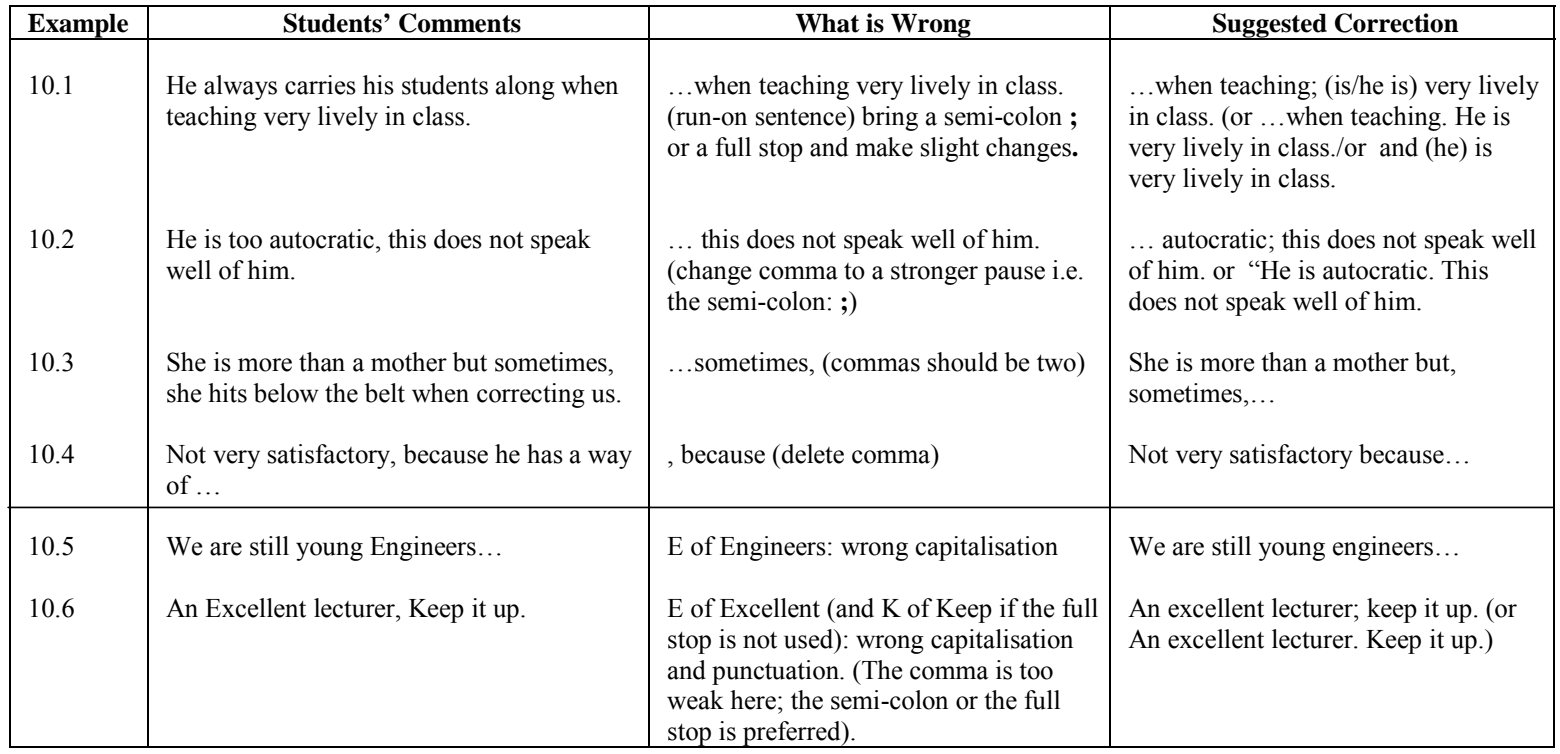

tion marks and they also misuse capital letters.

The problems of UMaT students in English could be traced to their poor grasp of basic grammatical knowledge from their pre-university education; carelessness; mother tongue $\left(\mathrm{L}_{1}\right)$ interference; wrong pronunciation; wrong spelling and malapropism due to vocabulary problems, lack of awareness of their audience; preference for nonstandard language use, and inadequate motivation to speak and write good English.

We conclude that our assumption is true, that is UMaT students have problems in English which are similar to those of students in other Ghanaian universities.

\section{Recommendations}

To overcome their difficulties in English, first,
UMaT students should read good materials to broaden their lexicon and increase their level of confidence; be cautious when they speak and write English and edit whatever they write; avoid speaking pidgin English; acquire good dictionaries and use them well; discard the erroneous notion that one can be understood in whatever faulty English, spoken or written, and therefore one does not need to speak or write faultless English; and remember that language is a skill - it requires more practice to get better. Second, lecturers must try to correct errors of the English language that they can detect in students' exercises and possibly discuss them; they could also award marks for language to force the students to put more effort into their writing. Lastly, the Academic Board of the University should consider extending the Communication Skills courses beyond the first year and should also 
encourage lecturers of all disciplines to mark all exercises and examinations not only for content but also for English.

\section{Acknowledgement:}

The author is grateful to the Planning and Quality Assurance Unit (PQAU) of the University of Mines and Technology for making the data accessible, to Prof. Kari Dako of University of Ghana, Legon, for providing useful suggestions and encouragement and to the anonymous reviewer for offering constructive criticism and suggestions and also for making corrections in the original manuscript.

\section{References}

Adu-Darko, P., Appiah, M. and Boahen, A. R. (2008), The Effects of Pidgin English on the Performance of Senior Secondary School Students in the English Language, A Study of Some Selected Schools in the Cape Coast Municipality, Dept of Arts and Social Science, UCC, Cape Coast, 40 pp.

Anyidoho, L.A. (2002). "Analysis of the Writing of Final Year University Students", Ghanaian Journal of English Studies, No. 1, Kropp Dakubu, M. E. (ed), Sedco, Accra, pp. 58-72.

Anon. (1998), Chief Examiners' Reports, Senior Secondary School Certificate Examination, November-December, The West African Examinations Council, Accra, 215 pp.

Anon. (1999), Chief Examiners' Reports, Senior Secondary School Certificate Examination, November-December, The West African Examinations Council, Accra, 325 pp.

Anon. (2003), Chief Examiners' Reports, Senior Secondary School Certificate Examination for School Candidates, July-August, The West African Examinations Council, Accra, $413 \mathrm{pp}$.

Anon. (2005), Chief Examiners' Reports, (Core and Universal Subjects), Senior Secondary School Certificate Examination, July, The West African Examinations Council, Accra, $73 \mathrm{pp}$.

Anon. (2006), Assessment of Course Lecturer Performance for the Second Semester of the 2005/2006 Academic Year, Planning and Quality Assurance Unit, UMaT, Tarkwa, 133 pp.

Awuah-Boateng, P. A. K. (1998), “An Analysis of Students' Errors based on a Diagnostic Test for First Year Students at the Beginning of the 1996/97 Academic Year," Dept of English, UCC, Cape Coast, 69 pp.

Bawa, A. (1992), "Error Analysis of Written
Grammar: A Case Study of UCC Practice SSS 1," Unpublished Long Essay, Dept of English, UCC, Cape Coast, 51p.

Criper, L. (1971), "A Classification of Types of English in Ghana", Journal of African Lan guages, 10.3, pp. 6-17.

Dako, K. (1997), "Features of Stylistic Versatility in English as Observed in the Writing of English Graduates", English in Ghana, Kropp Dakubu, M. E. (ed), GESA, Black Mask, Accra, pp. 263-274.

Dako, K. (2002), "Pidgin as a Gender Specific Language in Ghana," Ghanaian Journal of English Studies No. 1, Kropp Dakubu, M. E., Adika, G. and Komasi, M. (eds), Sedco, Accra, pp. 73-82.

Dako, K. (2003), Ghanaianisms: A Glossary, Ac cra, Ghana Universities Press, 234 pp.

Dako, K., Denkabe, A. and Forson B. E. (1997), "The Ghanaian University Students" Knowledge of Grammar", English in Ghana, Kropp Dakubu, M. E. (ed), GESA, Black Mask, Accra, pp. 53-68.

Dzontoh, D. K. (1996), "Error Analysis of Senior Secondary School Written English: The Case of Bisease Senior Secondary Com mercial School", Unpublished Long Essay, Dept of English, UCC, Cape Coast, 57 pp.

Edu-Buandoh, D. (1997), “A Preliminary Report on the Study of Error Patterns in the Writ ten Essays of Senior Secondary Students," English in Ghana, (ed), Kropp Dakubu, M. E., GESA, pp. 195-210.

Gbeze, R. K. (1997), "Error Analysis of Commu nicative Skills Examination Scripts of the University of Cape Coast", Unpublished Long Essay, Dept of English, UCC, Cape Coast, 57 pp.

Gogovi, G. A. K. (1997), "Intensifier + Verb Col location in English: A Case Study of PostDiploma Usage in the University College of Education, Winneba," English in Ghana, (ed) Kropp Dakubu, M. E., GESA, Accra, pp. 46-52.

Gyasi, I. K. (1990), "The State of English in Ghana", English Today 23, pp. 24- 26.

Gyening, R. (2008), "The Past and Principal Forms of Irregular Verbs: A Case Study of Sefwi-Wiaso Senior High School",Un published Long Essay, Dept. of English, UCC, Cape Coast, 60 pp.

Hyde, F. B. (1988), "Some Problems on Second Language Acquisition (with Special Refer ence to the Written English of Ghanaian Students in Secondary Schools," Unpublished MPhil Thesis, Dept of Linguistics, UG, Legon, 155 pp.

Nettey, R. C. (2001), "Linguistic Introduction among Male Students at the University of Ghana, Legon: a Micro Study, Unpublished 
Long Essay, Dept of English, UG, Legon, 57 pp.

Nkansah, S., Afeadi, S., Gedze, S. K. and Acquaye, P. (2008), "The Use of Modal Auxiliaries can, could, may, might, will, and would among the Students of Fijai Senior High School in the Sekondi District of the Shama Ahanta East Metropolis", Unpublished Long Essay, Dept of English, UCC, Cape Coast, 38 pp.

Odamtten, H., Denkabe, A. and Tsikata, I. E. (1994), "The Problem of English Language Skills at the University Level - A Case Study of First Year Law and Administration Students", Legon Journal of the Humanities, Vol. 7, pp. 95-125.

Owusu-Ansah, L. K. (1997), "Nativisation and the Maintenance of Standards in Non-Native Varieties of English", English in Ghana, Kropp Dakubu, M. E. (ed), GESA, Black Mask, Accra, pp. 23-33.

Quirk, R. and Greenbaum, S. (1976), A University Grammar of English, Longman, New Delhi, 484 pp.

Sey, K. A. (1973), Ghanaian English, Macmillan, London, $177 \mathrm{pp}$.

Tettey, O. O. (1996), "Error Analysis in English Language: A Case Study of Senior Secondary School Students of Holy Child School," Unpublished Long Essay, Dept of English, UCC, Cape Coast, 27 pp.

Twum-Barimah, E. (1996), "Error Analysis of Written Grammar of Senior Secondary Schools: A Case Study of UCC Practice SSS1-SSS3," Unpublished Long Essay, Dept of English, UCC, Cape Coast, 58 pp.

Yankson, K. E. (1994), Better English through Concord for West African Students, revised ed. Hampton Press: Cape Coast, 89 pp.

Yankyera, A. (1996), “Analysis of Errors made by Senior Secondary School Students in Written English. A Case Study of Gomoa Senior Secondary School", Unpublished Long Essay, Dept of English, UCC, Cape Coast, 77 pp.

\section{The Author:}

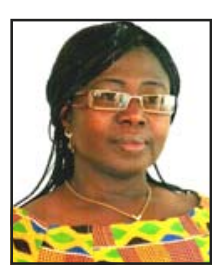

Patricia Beatrice Mireku-Gyimah

(Mrs) is currently a Lecturer at the University of Mines and Technology (UMaT), Tarkwa. She holds BA (Hons) Degree in English and French (combined) and Diploma in Education obtained concurrently in 1981 from the University of Cape Coast (UCC); MPhil Degree in Educational Planning and Administration obtained in 1998 also from UCC; and Postgraduate Diploma in French obtained in 1985 from the Université de Bordeaux III, France. She is currently working on her $\mathrm{PhD}$ in English at KNUST. Until joining UMaT in 2004, she was a part-time lecturer of Communication Skills (at UMaT) and a tutor of English and French at Tarkwa Senior High School where, at different times between 1981 and 2004, she held the positions of Head of French, Head of Languages (English and French), Assistant Headmistress (Administration) and Acting Headmistress. She is a member of the African Literature Association (ALA). 